\title{
Game Design to Introduce Pets
}

\author{
Wahyu Febriyanto \\ Game Technology Departement, Faculty of Computer Science \\ Soegijapranata Catholic University \\ Jl.Pawiytan Luhur IV, Semarang, Indonesia \\ wahdoer@gmail.com \\ T. Brenda Chandrawati .ST., MT \\ Game Technology Departement, Faculty of Computer Science \\ Soegijapranata Catholic University \\ Jl.Pawiytan Luhur IV, Semarang, Indonesia \\ brenda@unika.ac.id \\ Erdhi Widyarto N .ST., MT \\ Game Technology Departement, Faculty of Computer Science \\ Soegijapranata Catholic University \\ Jl.Pawiytan Luhur IV, Semarang, Indonesia \\ erdhi@unika.ac.id
}

\begin{abstract}
Introduction of animals from an early age can make children to love animals, especially pets. Children are the easiest group to receive stimulation, such as for example the stimulation of introducing children to the pet. Various media are used by parents to introduce pet. For examplle, by the media of books, multimedia, etc. One of the interesting media to introduce pet is with game. Of these problems then need to know how to make concept and design game to introduce pets for children age 3-6 years. In this paper, the author formulates how to make pet game design include game genre, user interface design, image model selection, game characters, and game engine. The expected design of this game can be formulation of learning through proper game as a learning tool children. Game design is derived from this writing by using model 2dimensional images are funny and interesting coloring. And combine several game genres into one, or use the mini games that children do not get bored quickly. Design of GUI (Graphical User Interface) is made as simple as possible so that children easily understand in playing this game, but also must use an interesting image.
\end{abstract}

Keywords-Game, Education,Introduction of animals, Game Design, Interactive Learning

\section{INTRODUCTION}

Introducing pets can be taught by parents from an early age. The child is expected to be motivated more loving pet, especially living creatures. Childhood is a period where they can be specifically receptive to the stimuli given to him. This time child is very sensitive when given stimulus, which stimulus in here is the introduction of animals.

If the child is given a good stimulus, then as adults they will remember the good stimulus[1].

However, formal methods applied in schools are still using methods that make teachers and students as a learning center as well as the objects they emphasize mastery oriented teaching materials text or often known by the traditional method[2]. Then need other methods are more fun so that children are more interested and easily understand the material presented as an alternative method of learning. One method that is deemed suitable by using interactive media. One is the interactive media with educational games.

Game is an activity with rules aiming to have fun and also be used for children's learning media. Through the game as a means of child's play, game can also be applied as a method of learning to improve children's interest in learning. In addition, children can play through interactive games, 
children can also get the science of learning pasted on game[3].

From the description above to motivate children to know and love a pet, then the authors will make the introduction of designer pet game for children of early age. The design of the game is intended for children aged 3-6 years.

\section{LITERATURE REVIEW}

\subsection{Understanding of learning media}

Media is a component of a learning resource in which there is an element that can distribute the materials provided, for example the media in here is game [4]. In other words, media is the link between learning material to children early age who receive material.

Meanwhile, the notion of learning is a process of interaction performed by the students, in this context of the early childhood learning resources such as teachers, books and other.The statement is in the Law of the Republic of Indonesia Number 20 Year 2003 on National Education System.

According Latuheru [5]learning media is a collection of tools, materials, and techniques that are used as a means of learning to get interaction between learners with learning resources appropriately so efficient.

The conclusion that can be drawn from above statement is the instructional media components that support the interaction between learners with learning resources, resulting in a process of interaction through the link between learners and learning resources.

\subsection{Media interactive learning with games}

Interactive learning model can be interpreted as a model of learning in children with direct approach in children by providing questions to the child and immediately provide a response in the form of answers. In this way children become active, because it will look for answers through direct observation to get answers to these questions so that the child becomes responsive and active [6].

According to Halidah(2006)[6] there are several advantages to using media interactive learning for children to learn, namely:

- Learning is more attractive for innovative and interactive for children

- Teachers are required to be more creative in making learning media for children

- Teachers were able to combine text, pictures, and visualizations that can be accepted by the child

- Adding motivation for media teaching children learning fun

- Training children to be more independent because of frequent observation alone

\subsection{Understanding of game}

Game is an activity that aims to have fun, to have clear rules and can be used as a medium of learning children. In addition to children's playground media, games can also be used as a medium of learning for children, as long as there is an element of learning in the game[3].

\section{Benefits game}

Here are the benefits of using game as a means of education [7] :

- Showing the good side of game through teaching methods

- Giving students their own experience of teaching methods through games

- Showing examples of materials with fun learning through play

- Training students to get the game right in their daily lives

\subsection{Types of Games}

According to S. Henry(2010) [8]there are many types of games that are often played, among other types of games:

- Action games, game that requires reflexes in play and timeliness

- Action-Adventure,game that combines elements of action and adventure into one, and takes the time to play it, and fight against enemies and interact with other characters 
- Real Time Strategy, game that requires strategy and strong logic in play

- Fighting game, namely game has two characters fight each other to gain a victory, an example of such a mortal combat

- Racing game,game manifold agility to get the fastest time in the play, the player is required to have a trick in agility

- Role Playing games (RPG), game that uses logic techniques and tactics to strengthen a character, as well as explore the map in the game and also be able to solve the puzzle

- Slide scrolling games,in this type of game , the characters walk sideways to follow the movement running background and usually without limits

- Puzzle game, type of game that uses the mind to solve a problem and there is a time limit that is used to solve the problem

- Shooting game, type of game is targeting an enemy target in a way to shoot and hit the target

- Casual gametype of game that does not have an age limit, can be played by anyone and does not have to use a special ability in playing.

\subsection{Game elements}

According to V. W. Febriani and N. A. Wijaya (2014)[9], stage of game development are elements that need to be considered, namely:

- Audio

without audio a game will be very less when being played, as the audio given its own color to the game. But in the selection of audio must be in accordance with what is made soas to support the game's story e.g. background noise, typically using instrumental

\section{- Programmer}

In making a game, a programmer must consider the effectiveness of the code used for the results of the games that made size is not large so that people do not hesitate to download the game

- Game Design

In this case the game makers should be able to make the design of the game is interesting, so children love. Including background game design, the layout of the title, font selection and more

- Characters

Characters representing the children who play in the game, for example, children aged 5 years is usually the character of plants, animals, and children themselves

- Storyline

Storyline becomes next most important aspect in making the game, passing easily understood story line will attract children to play. This scenario can be supported with text, video, and audio

\section{RESEARCH METHODOLOGY}

\section{Design system method}

In building a game, it takes the main data as reference data used to design and define the genre as well as the type of game that will be created.

The data used to determine the genre and the game models in this study are data derived from observations and pre-test questionnaires are distributed to 34 respondents parents who have a child with a vulnerable age 3-6 years.

\section{RESULTS AND DISCUSSION}

\subsection{Design system game}

From the observation and questionnaire obtained the gameplay system as Figure 4.1 above. Users first time open the game to menu select language, to decide whether to wear Indonesian or English in playing this game. Then enter main window, is that there is a menu for land, air, and water. From each of menu still contains the sub-menu again that studying the menu and menu play. 


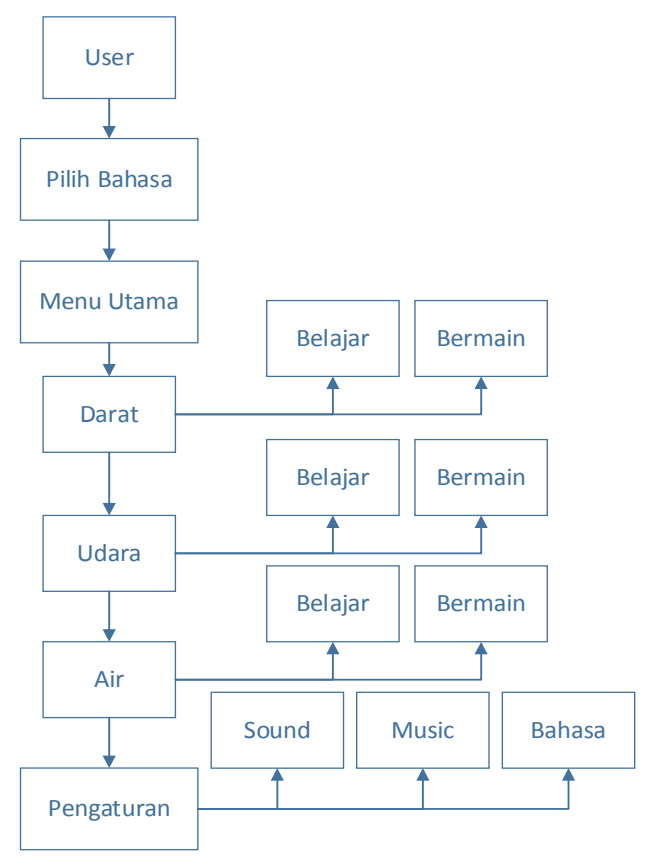

Figure 3.1 Flow gaming system

\subsection{Design GUI (Graphical User Interface)}

Views game by using a variety of colors affect the interest of play, especially children who like the funny pictures and colors vary.From the observation graphics look like children over to form a simple 2-dimensional accentuate the attractive colors.

\section{Design of menu learn}

This menu is where learning is given. This menu contains left and right navigation to replace animals, and then there is the voice and back button. Each menu has its own background to characterize the habitat of animals introduced. The following menu design sketch :

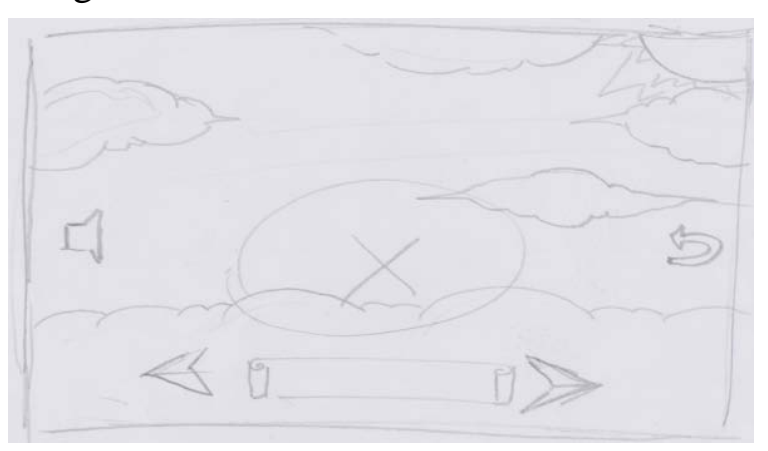

Figure 4.2Design of menu learn

After observation of a suitable shape and coloring user interface that is suitable for children to see the importance of the desired navigation key in the game.

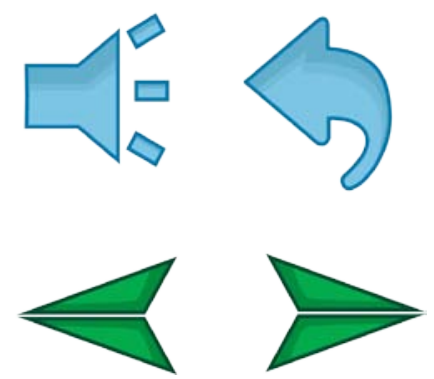

Figure 4.3 Design of button

\section{Design of menu playing}

Menu design plays are intended for children to play mini-games, but there are elements of repetition and learning materials on menu prior learning. As one example of the play menu of aquatic animals, such as the following:

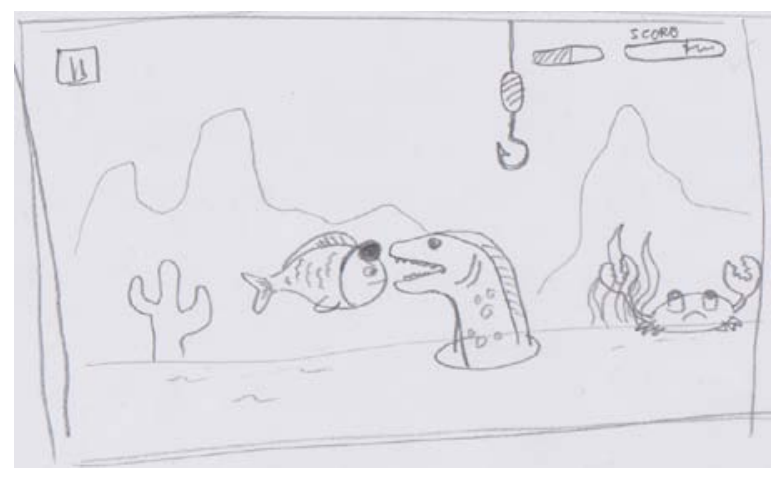

Figure 4.4Design of menu playing

Having known a rough idea of mini games that want to be created then needed to know user interface that is suitable for this mini-games. Includes several elements in it like a pause button, score, lifebar, and others

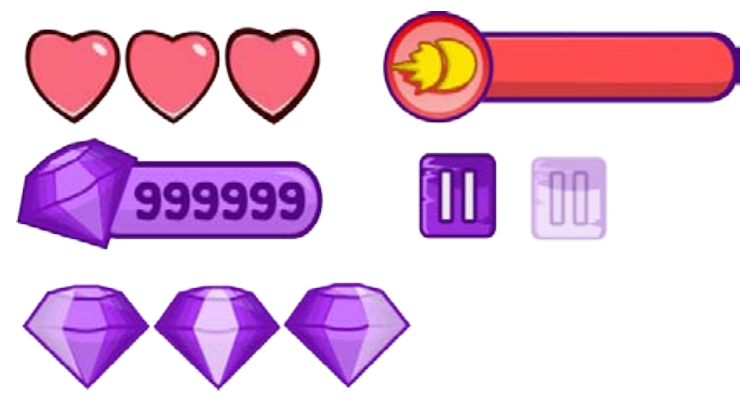

Figure 4.5Design of interface mini game

\section{Design other interface}

This design other interface includes the pause menu, game over, setting, and others. There are a few buttons as navigation, which is like a replay, resume, home. 


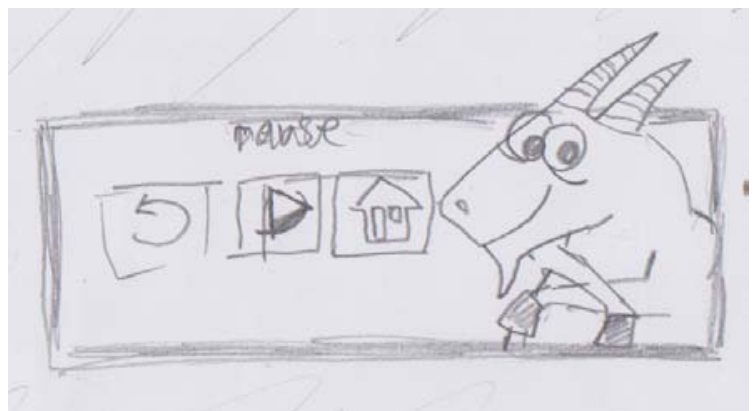

Figure 4.6Results of the draft pause

From the results of design sketches were made, obtained interface suitable for use in this game. For example, as shown below:

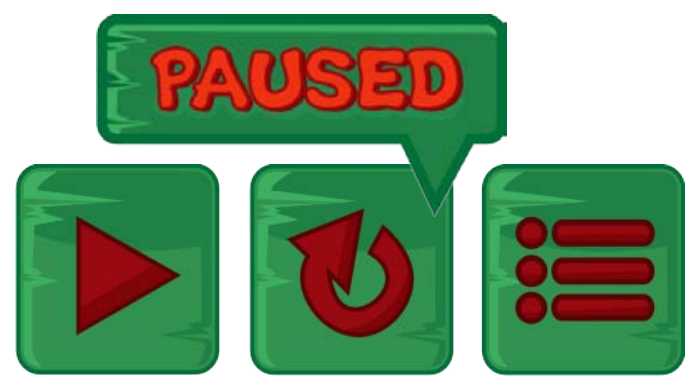

Figure 4.7Design of button pause

\subsection{Design of characters}

In addition to the user interface part of this game is no less important is the animal characters are introduced. Design is done by looking at pictures of native animals and then make a rough sketch of the animal's picture.

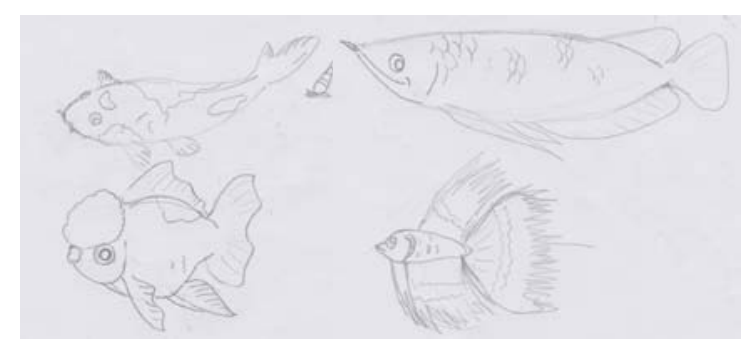

Figure 4.8 Design of character

In animal characters coloring design using shading technique, which uses light and dark shadows in order to obtain a real animal characters such as but not leaving the elements of the cartoon character. below is a picture of desired animal characters in this game :

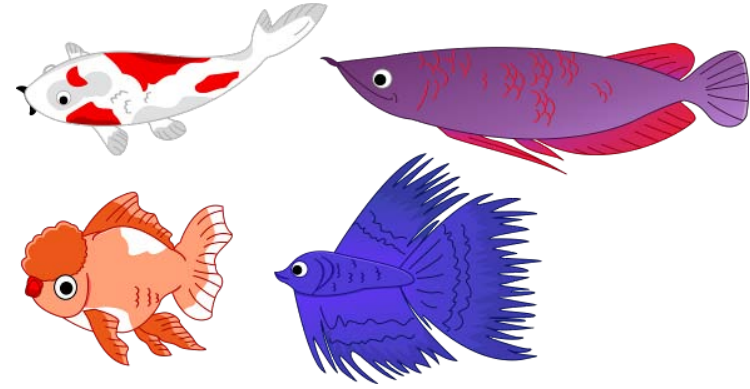

Figure 4.9Result of character design

\subsection{Image processing applications}

Many image processing applications are used to design, among others, Adobe Illustrator, Adobe Photoshop, CorelDraw, and more. But of the image processing application that is deemed suitable for this study, the authors chose CorelDraw because depending on the game you want to create in the form of two-dimensional. In addition, CorelDraw is a vector image processor that is easy to operate.

Many series CorelDraw, but the authors prefer CorelDraw X4. CorelDraw graphics design allows it to be used in accordance with the creativity of each person.

\subsection{Game engine}

Game engine is a software used to design and create a game.Game engine has a function as a means of rendering $2 \mathrm{D}$ and $3 \mathrm{D}$ graphics, physics engine, audio control, scripting, animation, AI (Artificial Intelligence), networking, streaming and setting chart[10].

From the observations of various types of game engine, the game engine is obtained construct2. Selected as many forums that discuss about making games with construct 2 and deemed competent enough to make this game.

\section{CONCLUSIONS}

From the above discussion, the results obtained are as follows:

1. Game design is suitable for children using 2 dimensional models that emphasize fun and interesting coloring

2. Having more than one game genres in one game, in order to avoid a bored child in playing the game 
3. Design of the GUI as simple as possible, but also must look attractive. In order for children to operate the games easily.

\section{ACKNOWLEDGMENT}

Wahyu Febriyanto gratefully acknowledged to Beasiswa Unggulan scholarship support from Bereau for Planning and International Cooperation, Ministry of Education and Culture of Indonesia.

\section{REFERENCES}

[1] E. G. Hainstock and B. Lumley, "Metode Pengajaran Montessori Untuk Anak Pra-Sekolah.” Pustaka Delapratasa, Jakarta, 1999.

[2] A. Budiningsih, "Belajar dan pembelajaran.” Rineka Cipta, Jakarta, 2005.

[3] J. M. Mintorogo, A. Adib, and A. W. Suhartono, "Perancangan Media Interaktif Pengenalan Alphabet Berbasis Alat Permainan Edukatif Untuk Anak Usia 2-4 Tahun,” J. DKV Adiwarna, vol. 1, no. 4, p. 13, 2014.
[4] A. Arsyad, "Media Pembelajaran." P.T Raja Grafindo Persada, Jakarta, 2009.

[5] J. D. Latuheru, "Media Pembelajaran Dalam Proses Belajar Mengajar Masa Kini.” Depdikbud, Jakarta, 1988.

[6] I. Halidah, "Perancangan Aplikasi Pembelajaran Berbasis Multimedia Untuk Anak Usia Dini," Pontianak, 2006.

[7] V. W. Febriani, D. S. Ardityo, and R. Sanjaya, "Idea Development on Games of Education for School' $s$ Entrepreneurship Sustainability," Int. J. Comput. Internet Manag., vol. 22, no. SP2, pp. 9.1-9.7, 2014.

[8] S. Henry, “Cerdas Dengan Game.” PT Gramedia Pustaka Utama, Jakarta, 2010.

[9] V. W. Febriani and N. A. Wijaya, "High School Technopreneurship Program to Increase the Educational Games for Students,” Int. J. Comput. Internet Manag., vol. 1, no. SP1, p. 25.1, 2014.

[10] A. Babastudio, "10 Game Engine Terbaik Saat Ini,” 2014. [Online]. Available: http://www.babastudio.com/blog/10game-engine-terbaik-saat-ini. [Accessed: 14-Jul-2016]. 